\title{
PENGGUNAAN APLIKASI PEMBELAJARAN ON-LINE BERBASIS E-LEARNING
}

\author{
SELPIONI IRZA \\ E-mail: selpioni.irza5142@gmail.com \\ * Program Studi Pendidikan Bahasa dan Sastra Indonesia, Universitas Riau
}

\section{Pengantar}

E-Learning merupakan sistem pendidikan yang menggunakan aplikasi elektronik untuk mendukung pengembangan kegiatan belajar mengajar dengan medial elektronika. E-Learning dapat mempermudah interaksi antara peserta didik dengan bahan materi, peserta didik dengan pengajar, maupun antara sesama peserta didik. E-Learning dapat membuat peserta didik saling berbagi infomasi dan mengakses bahan-bahan pelajaran setiap saat dan berulang-ulang, e-learning juga bukan hiburan bagi para peserta didik, dengan kondisi yang demikianlah peserta didik dapat lebih memantapkan penguasaanya terhadap materi pelajaran. Karena dengan kendala yang ada seperti proses belajar mengajar yang masih sering terganggu dan waktu belajar mengajar yang singkat mengakibatkan materi yang disampaikan guru kepada siswa masih banyak yang belum dipahami siswa. Dengan e-Learning memungkinkan terjadinya proses pendidikan tanpa melalui tatap muka langsung dan pengembangan ilmu pengetahuan kepada siswa bisa dilakukan dengan mudah. Melalui eLearning tersebut diharapkan dapat membantu para guru dalam memperbaiki efektivitas dan efesiensi proses pembelajaran serta membantu dalam pencapaian tujuan-tujuan pembelajaran. Selain itu, siswa diharapkan dapat lebih mudah memperoleh informasi-informasi tentang pembelajaran yang diikuti sehingga dapat lebih giat dalam mengikuti aktifitas belajar. Untuk itulah suatu konsep atau metode pembelajaran yang inovatif dan interaktif pun perlu dikembangkan agar dapat menumbuhkan minat siswa dalam belajar.

\section{Tindakan yang Dilakukan}




\section{A.E-Learning Sebagai Media Pembelajaran}

E-Learning Sebagai Media Pembelajaran E-learning dalam arti luas bisa mencakup pembelajaran yang dilakukan di media elektronik (internet) baik secara formal maupun informal. E-learning secara formal, misalnya adalah pembelajaran dengan kurikulum, silabus, mata pelajaran dan tes yang telah diatur dan disusun berdasarkan jadwal yang telah disepakati pihak-pihak terkait (pengelola e-learning dan pembelajar sendiri). Pembelajaran seperti ini biasanya tingkat interaksinya tinggi dan diwajibkan oleh perusahaan pada karyawannya, atau pembelajaran jarak jauh yang dikelola oleh universitas dan perusahaanperusahaan (biasanya perusahan konsultan) yang memang bergerak di bidang penyediaan jasa elearning untuk umum. E-learning bisa juga dilakukan secara informal dengan interaksi yang lebih sederhana, misalnya melalui sarana mailing list, e-newsletter atau website pribadi, organisasi dan perusahaan yang ingin mensosialisasikan jasa, program, pengetahuan atau keterampilan tertentu pada masyarakat luas (biasanya tanpa memungut biaya). Beberapa manfaat yang bisa dinikmati dari proses pembelajaran dengan e-learning, diataranya : Fleksibilitas, Independent Learning dan Biaya.

Pengembangan e-learning tidak semata-mata hanya menyajikan materi pelajaran secar online saja, namun harus komunikatif dan menarik. Materi pembelajaran didesain seolah peserta didik belajar dihadapan pengajar memalui layar komputer yang dihubungkan melalui jaringan internet. Untuk dapat menghasilkan e-learning yang menarik dan diminati dalam meningkatkan kualitas pembelajaran, ada tiga syarat hal yang wajib dipenuhi dalam merancang elearning, yaitu:

a. Sederhana, sistem yang sederhana akan memudahkan peserta didik dalam memanfaatkan teknologi dan menu yang ada, dengan kemudahan pada panel yang disediakan, waktu belajar peserta akan lebih efisien.

b. Personal, pengajar / guru dapat berinteraksi dengan baik dengan siswanya, seperti layaknya berkomunikasi di depan kelas. Dengan pendekatan dan interaksi yang lebih personal, peserta didik diperhatikan kemajuanya, serta dibantu segala persoalan yang dihadapi. 
c. Cepat, layanan yang ditunjang dengan kecepatan, respon yang cepat terhadap keluhan dan kebutuhan peserta didik, sehingga perbaikan pembelajaran dapat dilakukan secepat mungkin oleh pengajar atau pengelola.

\section{Sarana Pendukung}

\section{a. GoogleClassroom}

Google Classroom adalah aplikasi pembelajaran daring berbasis web yang dibuat untuk memudahkan kegiatan pembelajaran antara pengajar dengan peserta didik tanpa harus bertatap muka secara langsung. Google Classroom merupakan layanan dari Google for Education untuk membantu aktivitas komunikasi antara pengajar dengan peserta didik dalam pembelajaran. Google classroom memungkinkan Bapak/Ibu Guru melihat perkembangan peserta didik siapa saja yang sudah dan belum menyelesaikan tugas serta dapat langsung memberikan nilai dan masukan secara real-time. Peserta didik juga dapat dengan mudah mengakses dan menerima materi serta mengumpulkan tugas langsung melalui Google Classroom.

\section{b. Zoom}

Aplikasi meeting online yang paling dapat perhatian di masa pandemi seperti sekarang ini adalah Zoom. Tidak hanya digunakan oleh para pekerja kantoran yang diwajibkan bekerja dari rumah tetapi juga oleh para dosen dan mahasiswa untuk melakukan pembelajaran secara online.Bahkan aplikasi ini juga digunakan para pegiat seminar secara online atau yang biasa disingkat webinar. Sebelum membahas cara menggunakan Zoom, ada baikya kita kenali lebih dalam tentang Zoom dan apa saka fitur-fiturnya.Zoom adalah aplikasi komunikasi menggunakan video dan dapat digunakan dalam berbagai perangkat baik seluler maupun desktop.Aplikasi ini biasanya digunakan untuk melakukan tatap muka secara jarak jauh dengan jumlah peserta yang cukup banyak.

\section{c. GoogleMeet}

Google Meet adalah produk dari Google yang merupakan layanan komunikasi video yang dikembangkan oleh Google. Aplikasi ini adalah salah satu 
dari 2 aplikasi yang merupakan versi baru dari versi terdahulunya yaitu Google Hangouts dan Google Chat. Pihak Google sendiri telah menghentikan versi klasik Google Hangouts pada Oktober 2019 silam.

Setelah hanya mengundang dan secara diam- diam tanpa tercium publik, Google Meet dirilis untuk pengguna iOS saja namun pada Februari 2017 kemarin Google secara resmi meluncurkan Google Meet di bulan berikutnya. Layanan ini diluncurkan sebagai aplikasi konferensi video yang bisa ditonton hingga 30 peserta. Meet menjadi versi yang lebih kuat dibanding Hangouts pendahulunya karena Meet mampu ditampilkan pada aplikasi web, aplikasi Android dan iOS.

\section{d. Telegram}

Telegram adalah sebuah aplikasi layanan pengirim pesan instan multiplatform berbasis awan yang bersifat gratis dan nirlaba.] Klien Telegram tersedia untuk perangkat telepon seluler (Android, iOS, Windows Phone, Ubuntu Touch) dan sistem perangkat komputer (Windows, OS X, Linux). Para pengguna dapat mengirim pesan dan bertukar foto, video, stiker, audio, dan tipe berkas lainnya. Telegram juga menyediakan pengiriman pesan enkripsi ujung-ke-ujung opsional.

Telegram dikembangkan oleh Telegram Messenger LLP dan didukung oleh wirausahawan Rusia Pavel Durov. Kode pihak kliennya berupa perangkat lunak sistem terbuka namun mengandung blob binari, dan kode sumber untuk versi terbaru tidak selalu segera dipublikasikan, sedangkan kode sisi servernya bersumber tertutup dan berpaten. Layanan ini juga menyediakan API kepada pengembang independen. Pada Februari 2016, Telegram menyatakan bahwa mereka memiliki 100 juta pengguna aktif bulanan, mengirimkan 15 miliar pesan per hari.

Keamanan Telegram telah menghadapi pemeriksaan teliti yang menjadi perhatian; para kritikus mengklaim bahwa model keamanan Telegram dirusak oleh penggunaan protokol enkripsi yang dirancang khusus yang belum terbukti andal dan aman, dan dengan tidak mengaktifkan percakapan aman secara default. Telegram juga menghadapi kritik karena penggunaan skala luas oleh organisasi teroris Negara Islam (NIIS). NIIS telah merekomendasikan Telegram kepada para 
pendukung dan anggotanyadan pada Oktober 2015 mereka mampu melipatgandakan jumlah pengikut saluran resmi mereka menjadi 9.000 orang.

Aplikasionlinemerupakan situs aplikasi online yang penggunaan aplikasi ini membantu siswa dalam belajar secara mandiri dan dapat meningkatkan keaktivan kemandirian belajar siswa. Aplikasi ini dapat memudahkan guru dan siswa dalam proses pembelajaran. Dikatakan memudahkan karena dalam aplikasi ini guru bisa memberikan tugas dirumah dan siswa mampu mengerjakannya dengan baik. Kelebihan aplikasi ini dalam pembelajaran adalah memiliki situs online tiada batas dalam mencari informasi pembelajaran baik guru maupun siswa.

\section{Tindakan Solutif}

a. Jika Google Classroom tidak Bisa Dimaksimalkan maka bisa menggunakan zoom

b. Jika Zoom tidak Bisa Dimaksimalkan maka bisa menggunakan google meet

c. Jika Google Meet tidak bisa dimaksimalkan maka bisa menggunakan telegram

d. Jika Telegram tidak bisa dimaksimalkan maka bisa menggunakan aplikasi lainnya

\section{Simpulan}

Penggunaa aplikasi online untuk meningkatkan keaktivan kemandirian belajar siswa dapat membantu meningkatkan kemandrian siswa dalam belajar disekolah maupun dirumah. Aplikasi ini bertujuan untuk menguji siswa bisa atau tidaknya belajar mandiri supaya bisa meningkatkan kemandirian siswa dalam belajar. Era globalisasi persaingan semakin ketat dalam dunia pendidikan maupun dunia pekerjaan. Maka dari itu didiknya siswa sesuai era global baik guru maupun orang tua dan dalam pengawasan. 


\section{Referensi}

Zulhafizh. (2020). Orientasi Pelaksanaan Kurikulum Pembelajaran di SMA: Perspektif Guru. Jurnal PAJAR (Pendidikan dan Pendidikan Pendidikan), 4(2).

Zulhafizh, Z. (2021). QUALITY OF MAKING LESSON PLANS BY SENIOR HIGH SCHOOL TEACHERS IN SIAK REGENCY.

Anhar. 2010. PHP dan MSQL Secara Otodidak. Jakarta : PT. Transmedia

Boettcher, Judith V. 1999, Faculty Guide For Moving Teaching and Learning To The Web, LeagueFor Innovation in The Community College, USA

Clark, D. 1996. Financing Of Education in Indonesia, Asian Development Bank and ComparativeEducation Research Centre The University, Hongkong

Hamalik, Umar. 2016. Kurikulum Dan Pembelajaran. Jakarta : Bumi Aksara

Kadir, Abdul. 2014, Pengenalan Sistem Informasi. Yogyakarta : Andi OffsetKoran,

Jaya Kumar C. 2012. Aplikasi E-Learning Dalam Pengajaran dan Pembelajaran

Disekolah-Sekolah Malaysia : Cadangan Pelaksanaan pada sekenario Masa Kini,Pasukan Projek Rintis Sekolah Bastari Bagian Teknologi Pendidikan, KementrianPendidikan Malaysia.

Muhibbin Syah, M.Ed. 2016. Psikologi Belajar. Jakarta : Rajawali Pers

Onno W. Purbo. 2012. E-Learning Berbasis PHP dan MySQL. Jakarta : Elex Media Komputindo

Siahaan, S. (2002). (Pembelajaran Elektronik) Sebagai salah satu alternatif kegiatan pembelajaran.[On-Line]. Tersedia : Http//depdiknas.go.id [2 Januari 2017] 